ISSN: $2354-1431$

http://tckh.daihoctantrao.edu.vn/

\title{
Phát triển du lịch sinh thái ở Tuyên Quang: nghiên cứu trường hợp huyện Lâm Bình
}

\author{
Nguyễn Khải Hoàn ${ }^{a^{*}}$, Nguyễn Phuoong Thảo ${ }^{a}$, Nguyễn Văn Hiền ${ }^{b}$ \\ ${ }^{a}$ Truờng Đại học Tân Trào \\ ${ }^{b}$ Ủy ban nhân dân huyện Lâm Bình \\ *Email: a hoannk63@gmail.com
}

\section{Thông tin bài viết}

Ngày nhận bài:

$15 / 11 / 2018$

Ngày duyệt đăng:

$10 / 12 / 2018$

Tù khoá:

Phát triển $d u$ lịch; $d u$ lịch sinh thái; sinh thái Lâm Bìn; sinh thái Tuyên Quang.

\section{Tóm tắt}

Một trong những loại hình du lịch đang ngày càng phát triển mạnh mẽ, thu hút du khách trong nước và quốc tế, đó là loại hình du lịch sinh thái. Du lịch sinh thái được xem như một giải pháp hữu hiệu để bảo vệ môi trường sinh thái hướng tới sự phát triển bền vững thông qua quá trình làm giảm sức ép khai thác nguồn lợi tự nhiên, phục vụ nhu cầu của du khách, của người dân địa phương khi tham gia vào các hoạt động du lịch sinh thái gắn với cộng đồng. Bài viết này phân tích, làm rõ một số vấn đề về tiềm năng, thế mạnh và giải pháp phát triển du lịch sinh thái ở Tuyên Quang thông qua nghiên cứu trường hợp huyện Lâm Bình.

\section{1. Đặt vấn đề}

Thực hiện Kết luận số 28 KL/TU ngày 18/5/2016 của Ban Thường vụ Tỉnh ủy về nhiệm vụ, giải pháp phát triển du lịch giai đoạn 2016 - 2020; Kế hoạch số 51/KH-UBND ngày 23/6/2016 của Ủy ban nhân dân tỉnh về phát triển du lịch giai đoạn 2016 - 2020, Tuyên Quang đã quy hoạch 4 khu du lịch chính [9]: (i) Khu du lịch lịch sử - văn hóa và sinh thái Tân Trào; (ii) Khu du lịch trung tâm thành phố Tuyên Quang và vùng phụ cận; (iii) Khu du lịch Suối khoáng Mỹ Lâm và vùng phụ cận; (iv) Khu du lịch sinh thái Na Hang, Lâm Bình. Trong đó, chú trọng thu hút tiềm năng, thế mạnh về du lịch sinh thái của các điểm du lịch như: (i) Điểm du lịch lịch sử văn hóa và sinh thái Tân Trào và vùng phụ cận; (ii) Điểm du lịch lịch sử văn hóa và sinh thái Chiêm Hóa: Di tích lịch sử Kim Bình và hệ thống di tích kháng chiến; chùa Bảo Ninh Sùng Phúc, đền Bách Thần, lễ hội Lồng tông; làng văn hóa dân tộc Tày, thôn Tân Thịnh, xã Tân An; danh thắng thác Bản $\mathrm{Ba}$, xã Trung Hà...; (iii) Điểm du lịch sinh thái Na Hang: Hồ thủy điện Tuyên Quang; khu bảo tồn thiên nhiên Tát Kẻ Bản Bung; hệ thống núi đá, hang động; khám phá các làng văn hóa dân tộc Tày, Dao, Mông...; (iv) Điểm du lịch lịch sử văn hóa, sinh thái Lâm Bình: Thắng cảnh Thượng Lâm hệ thống núi đá, hang động - công viên địa chất Việt Nam; khám phá các làng văn hóa dân tộc Tày, Dao, Mông; chùa Phúc Lâm và các di chỉ khảo cổ...; (v) Điểm du lịch sinh thái Hàm Yên: Động Tiên, rừng Cham $\mathrm{Chu}$, đền Thác Cái, du lịch sinh thái nhà vườn; hồ Khởn...; (vi) Điểm du lịch lịch sử văn hóa nghỉ dưỡng Yên Sơn: Di tích lịch sử cách mạng Lào Làng Ngòi, Đá Bàn, xã Mỹ Bằng; chùa Phật Lâm; nghỉ dưỡng suối khoáng Mỹ Lâm, các làng văn hóa dân tộc Cao Lan, Quần Trắng; thể thao (golf, tennis...). Các tour, tuyến du lịch đều đảm bảo các điệu kiện về kết nối các khu du lịch, điểm du lịch trong phạm vi địa phương; có biện pháp bảo vệ cảnh quan, môi trường và cơ sở dịch vụ phục vụ khách du lịch dọc theo tuyến du lịch. Tuy nhiên các tua, tuyến du lịch hoạt động còn nhỏ lẻ, chưa tương xứng với tiềm năng phát triển du lịch của tỉnh và chưa thu hút được nhiều khách du lịch, đặc biệt là khách du lịch quốc tế đến với Tuyên Quang.

Thực hiện Nghị quyết số 08-NQ/TW ngày 16/01/2017 của Bộ Chính trị về phát triển du lịch trở 
thành ngành kinh tế mũi nhọn, Tỉnh ủy, Ủy ban nhân tỉnh đã chỉ đạo các huyện, thành phố xây dựng các kế hoạch triển khai Chương trình hành động số $25-\mathrm{CTr} / \mathrm{TU}$ ngày 27/6/2017 của Ban Thường vụ Tỉnh ủy thực hiện Nghị quyết số $08-\mathrm{NQ} / \mathrm{TW}$ ngày 16/01/2017 của Bộ Chính trị về phát triển du lịch trở thành ngành kinh tế mũi nhọn. Tăng cường liên kết, hợp tác phát triển $\mathrm{du}$ lịch liên vùng, liên tỉnh để đẩy mạnh du lịch phát triển, như thường xuyên trao đổi nghiệp vụ, kinh nghiệm quản lý, khai thác phát triển du lịch với các tỉnh nằm trong chương trình hợp tác phát triển: Cao Bằng, Bắc Kạn, Lạng Sơn, Thái Nguyên, Hà Giang, Hà Nội, Vĩnh Phúc...Nghiên cứu trường hợp huyện Lâm Bình là một trong các ví dụ điển hình cho khai thác tiềm năng, thế mạnh của địa phương trong việc phát triển du lịch sinh thái gắn với du lịch cộng đồng tại tỉnh Tuyên Quang.

\section{Nội dung nghiên cứu}

\subsection{Du lịch sinh thái và tiềm năng phát triển du lịch sinh thái ở Tuyên Quang}

Du lịch sinh thái là loại hình du lịch dựa vào thiên nhiên và văn hóa bản địa, gắn với bảo vệ môi trường, có đóng góp cho nỗ lực bảo tồn và phát triển bền vững, với sự tham gia tích cực của cộng đồng địa phương. Ngoài ý nghĩa góp phần bảo tồn tự nhiên, bảo vệ đa dạng sinh học và văn hóa cộng đồng; sự phát triển du lịch sinh thái đã và đang mang lại những nguồn lợi kinh tế to lớn, tạo cơ hội tăng thêm việc làm và nâng cao thu nhập cho quốc gia cũng như cộng đồng người dân các địa phương, nhất là người dân ở các vùng sâu, vùng xa nơi có các khu bảo tồn tự nhiên và các cảnh quan hấp dẫn. Ngoài ra, du lịch sinh thái còn góp phần vào việc nâng cao dân trí và sức khỏe cộng đồng thông qua các hoạt động giáo dục môi trường, văn hóa lịch sử và nghỉ ngơi giải trí [4][7].

Luật Du lịch 2017 đã chỉ rõ: "Du lịch sinh thái là loại hình du lịch dựa vào thiên nhiên, gắn với bản sắc văn hoá địa phương, có sự tham gia của cộng đồng dân cư, kết hợp giáo dục về bảo vệ môi trường”; " Du lịch cộng đồng là loại hình du lịch được phát triển trên cơ sở các giá trị văn hóa của cộng đồng, do cộng đồng dân cư quản lý, tổ chức khai thác và hưởng lợi"[8]. Như vậy, du lịch sinh thái và du lịch cộng đồng có mối quan hệ mật thiết với nhau, không thể tách rời mà thường xuyên bổ sung cho nhau xét trên tất cả các phương diện.

Mặc dù du lịch sinh thái được xem là loại hình du lịch đặc thù, có tiềm năng, được ưu tiên phát triển trong Chiến lược phát triển du lịch Việt Nam khi bước vào thế kỷ XXI, song cho đến nay việc phát triển loại hình du lịch này còn nhiều hạn chế, do nhận thức của các bên liên quan (chính quyền, doanh nghiệp, cộng đồng địa phương, khách du lịch) về loại hình du lịch này còn chưa thật đầy đủ và chuẩn tắc. Sự phát triển của du lịch sinh thái hiện nay còn chưa tương xứng với tiềm năng phong phú và đa dạng của Việt Nam. Các hình thức hoạt động của loại hình du lịch này mới chỉ mang ý nghĩa tham quan, hưởng thụ môi trường để tái tạo sức khỏe, ít đạt được ý nghĩa về nâng cao nhận thức, giáo dục để du khách có trách nhiệm đối với việc bảo tồn các giá trị văn hóa bản địa, cũng như chưa mang lại những giá trị đích thực đối với lợi ích của cộng đồng [1][2][3].

Tuyên Quang là một tỉnh thuộc khu vực trung du miền núi phía Bắc Việt Nam, là một điểm đến du lịch của du khách trong và ngoài nước, có tài nguyên du lịch rất dồi dào, khí hậu trong lành, giao thông đi lại khá thuận tiện, là một nơi có điều kiện thuận lợi để phát triển du lịch sinh thái. Với những đặc điểm tự nhiên như vậy nên trong những năm qua, tỉnh Tuyên Quang đã đạt được những kết quả đáng khích lệ trong việc phát triển du lịch: số lượng khách du lịch đến thăm quan tăng trưởng đều qua các năm, đầu tư của tỉnh và các doanh nghiệp vào du lịch có xu hướng ngày càng tăng. Kết quả thống kê 02 năm gần đây cho thấy: (i) Năm 2017, tổng lượt khách du lịch đạt 1.590 .900 lượt, đạt 107\% kế hoạch năm, tăng 10,4\% so với năm 2016. Tổng thu từ khách $\mathrm{du}$ lịch đạt 1.380 tỷ đồng, bằng 108\% kế hoạch năm, tăng 11,4\% so với năm 2016; (iii) Năm 2018, thu hút 1.760.600 lượt khách du lịch, đạt 105\% kế hoạch năm, tăng 10,7\% so với cùng kỳ năm trước. Tổng thu từ khách du lịch đạt 1.556 tỷ đồng, bằng $103 \%$ kế hoạch năm, tăng $12,8 \%$ so với cùng kỳ năm trước [9].

Tuy nhiên, bên cạnh nhưng kết quả đạt được, phát triển du lịch sinh thái ở Tuyên Quang còn nhiều hạn chế như: (i) Phát triển du lịch sinh thái vẫn còn chưa tương xứng với tiềm năng, thế mạnh của tỉnh; (ii) Các hoạt động du lịch sinh thái chưa thực sự hấp dẫn, đa dạng; (iii) Cơ sở hạ tầng, vật chất kỹ thuật phục vụ khách du lịch còn nhiều hạn chế; (iv) Công tác quảng bá, xây dựng sản phẩm du lịch sinh thái chưa được quan tâm đúng mức; (v) Đội ngũ cán bộ quản lý du lịch, hướng dẫn viên du lịch am hiểu về du lịch sinh thái còn thiếu và yếu [5][9]. Để khắc phục những hạn chế này, cần có những nghiên cứu chuyên sâu về phát triển du lịch nói chung và phát triển du lịch sinh thái nói riêng tại tỉnh Tuyên Quang, đặc biệt là tại các huyện có tiềm năng phát triển du lịch sinh thái gắn với du lịch cộng đồng. 
2.2. Nghiên cứu trường hợp phát triển du lịch sinh thái gắn với du lịch cộng đồng tại huyện Lâm Bình

2.2.1. Tiềm năng phát triển du lịch sinh thái gắn với du lịch cộng đồng

Lâm Bình là huyện vùng sâu, vùng xa, vùng cao phía Bắc của tỉnh Tuyên Quang, diện tích tự nhiên 78.495,51 ha; phía Đông giáp huyện Nà Hang (Tuyên Quang), Đông Bắc giáp huyện Bắc Mê (Hà Giang); phía Tây và Tây Bắc giáp huyện Vị Xuyên và huyện Bắc Quang (Hà Giang); phía Nam giáp huyện Chiêm Hóa (Tuyên Quang). Huyện Lâm Bình cách Hà Nội khoảng 280km; cách Thành phố Tuyên Quang khoảng $120 \mathrm{~km}$; cách Cao nguyên đá Hà Giang khoảng $150 \mathrm{~km}$; cách Hồ Ba Bể, huyện Pác Nặm, tỉnh Bắc Kạn khoảng $130 \mathrm{~km}$ và cách Hồ Núi Cốc tỉnh Thái Nguyên 180km.

Địa hình Lâm Bình hiểm trở, có nhiều núi đá vôi, thấp dần từ Bắc xuống $\mathrm{Nam}$; bị chia cắt rất lớn, nhiều vùng gần như biệt lập. Hầu hết các đỉnh núi có độ cao khoảng 800 đến $1.000 \mathrm{~m}$, nhiều đỉnh núi cao trên $1.000 \mathrm{~m}$; núi thường chia thành nhiều dãy với nhiều đỉnh núi nối tiếp nhau tạo nên sự trùng điệp, đặc biệt khu vực Thượng Lâm, Khuôn Hà, Lăng Can núi chia thành từng quả, xen giữa các dãy núi là những cung đường uốn lượn quanh co, những bản làng xinh đẹp, những nương lúa, nương ngô xanh mướt. Khu vực cao nhất là thuộc vòng cung Lô-Gâm với hệ thống núi non trùng điệp, hùng vĩ, hòa quyện giữa đại ngàn xanh thẳm, soi bóng xuống mặt hồ Tuyên Quang, tạo nên một bức tranh thiên nhiên kỳ vĩ, hiếm nơi nào có được [11].

Lâm Bình là một trong những huyện có diện tích rừng tự nhiên lớn nhất toàn quốc, độ che phủ rừng đạt trên $80 \%$ so với diện tích toàn huyện. Thảm rừng nhiệt đới xanh quanh năm, hệ động vật, thực vật đa dạng, phong phú, trong đó có nhiều loài quý hiếm như: Pơ mu, thông tre, thông đỏ, nghiến, trai, đinh, sến, dổi, các loài lan kim tuyến và một số loài dược liệu quý (cây một lá, thất diệp nhất chi hoa,...); Động vật có: Voọc đen má trắng, vượn, khỉ, hươu, nai, lợn rừng, mèo rừng, cu li, sóc, cầy, nhím và một số loài khác.

Diện tích hồ Tuyên Quang rộng trên 8.000ha, chia 02 tuyến (dọc theo sông Gâm và sông Năng trước đây). Lòng hồ thuộc địa bàn huyện Lâm Bình quản lý dọc theo tuyến sông Gâm kéo dài đến địa phận huyện Bắc Mê, tỉnh Hà Giang. Lòng hồ là nơi sinh sống, nuôi trồng của nhiều loài cá đặc sản như: dầm xanh, anh vũ, chiên, lăng, bỗng, chạch, nheo... Cùng với lòng hồ rộng lớn, trên địa bàn huyện có hệ thống các con suối lớn, nhỏ khác nhau, đây là nơi cung cấp nước cho sinh hoạt, đời sống và sản xuất của nhân dân các dân tộc trong vùng, đồng thời các con suối uốn quanh các bản làng, tạo nên nét thơ mộng, bình yên của miền sơn cước.

Lâm Bình được thiên nhiên ban tặng cho nhiều danh lam, thắng cảnh đẹp, trong đó phải kể đến: Danh thắng Quốc gia 99 ngọn núi Thượng Lâm huyền thoại, nơi được coi là Vịnh Hạ Long cạn giữa đại ngàn; Phong cảnh, núi non Khuôn Hà, Lăng Can, Bình An, Thổ Bình, Hồng Quang, Xuân Lập, Phúc Yên; hòn Cọc Vài (cọc buộc trâu của chàng Khổng lồ Tài Ngào), Núi Đổ địa phận giáp ranh giữa huyện Lâm Bình, tỉnh Tuyên Quang và huyện Bắc Mê, tỉnh Hà Giang; Đèo Ái Au, xã Thượng Lâm; đèo Kéo Nàng, xã Lăng Can; đèo Tát Nga, Khau Cau, xã Phúc Yên... Mỗi danh lam, thắng cảnh đều có vẻ đẹp tự nhiên, kỳ vĩ và chứa đựng những sự tích, huyện thoại, gắn với sinh hoạt, đời sống ngàn đời của đồng bào các dân tộc nơi đây.

Hòa quyện với núi rừng là các thác nước: Thác Bản Lòa, Nặm Me, Khuổi Súng, Tát Ngà... trên khu vực Hồ Lâm Bình; Thác Vằng Dân, Tát Trà, xã Lăng Can; Thác Khủng Cho, xã Hồng Quang; Thác Hang, thôn Bản Bon, xã Phúc Yên... Các thác nước ở Lâm Bình gồm nhiều tầng thác, nguyên sơ. Đặc biệt gần đây, huyện mới phát hiện một hệ thống hang động rộng lớn, nguyên sơ với nhiều thạch nhũ được đánh giá là đẹp không kém các nhũ đá ở Động Phong Nha, tỉnh Quảng Bình, như: Hang Khuổi Pín, hang Nặm Thuổm, hang Giếng trời, hang Khuổi Poóng, hang Lũng Nhòi, động Song Long.

Cùng với các danh lam, thắng cảnh, Lâm Bình còn có các di tích lịch sử, khảo cổ, tâm linh: Di tích Quốc gia đền Pú Bảo, chùa Phúc Lâm, xưởng Quân khí H52 của anh hùng lao động Ngô Gia Khảm, đền Pác Vãng, đền Bà Chủa (Bà Chúa); chùa Ông, chùa Bà, đền Nà Thếm, hang Xum Lôm, hang Phia Vài (nơi phát hiện 02 ngôi mộ táng có niên đại trên dưới 12 nghìn năm).

Với những đặc điểm tự nhiên đặc trưng, riêng biệt trên, hiện nay, tỉnh Tuyên Quang đang lập hồ sơ để đề nghị công nhận Khu bảo tồn thiên nhiên Na Hang-Lâm Bình là Khu danh thắng Quốc gia đặc biệt; đó cũng là phần lõi của các bộ phận hợp thành Khu Lâm Bình-Na Hang-Ba Bể đang được tỉnh lập hồ sơ trình UNESSCO công nhận là Di sản thiên nhiên thế giới.

Lâm Bình có 08 đơn vị hành chính cấp xã, 76 thôn, bản; dân số toàn huyện gần 34 nghìn người, với trên 12 dân tộc cùng chung sống, dân tộc thiểu số chiếm trên $95 \%$, trong đó: Dân tộc Tày chiếm 62\%, Dao trên 25\%, Mông $6 \%$, PàThẻn $2 \%$ còn lại là các dân tộc khác. Đặc 
biệt, duy nhất ở Việt Nam, tại thôn Thượng Minh, xã Hồng Quang, huyện Lâm Bình có tộc Người Thủy sinh sống; tộc Người Thủy có tiếng nói, trang phục, văn hóa tín ngưỡng, phong tục tập quán, nguồn gốc riêng biệt [10][11].

Các dân tộc cơ bản còn giữ nguyên nét văn hóa truyền thống, từ tiếng nói, chữ viết, trang phục, tín ngưỡng, tri thức dân gian, nghề truyền thống (nghề dệt thổ cẩm, nghề thêu, nghề rèn, mây giang đan, nghề làm bún cổ truyền,...), các làn điệu dân ca, dân vũ (hát Then, hát quan làng, hát Páo dung, hát cọi, múa khèn,...), trò chơi dân gian, kiến trúc nhà ở (nhà sàn của người Tày, nhà đất của người Dao, Pà Thẻn, nhà trình tường của người Mông...) và các lễ hội đặc trưng (Lễ hội xuống đồng của người Tày, lễ cấp sắc của người Dao, lễ hội nhảy lửa của người Pà Thẻn...).

Lâm Bình không chỉ được biết đến với nhiều thắng cảnh đẹp, nhiều lễ hội và phong tục độc đáo mà còn là nơi chứa đựng nét văn hóa ẩm thực truyền thống độc đáo hết sức lý thú và hấp dẫn du khách. Nhiều sản phẩm đặc sản của địa phương như: mật ong, nấm hương rừng, chè Khau mút, rượu ngô, rượu thóc men lá, cá đặc sản lòng hồ,... và các món ăn đặc sản địa phương như: Thắng cố, mèn mén, thịt chua, cá chua, cá mắm ruộng, xôi ngũ sắc, thịt lợn bí, cá khuy suối lam ống nứa, bánh trứng kiến, bún cổ truyền, ốc suối, rêu suối, rau rừng, thịt trâu gác bếp, da trâu khô, các loại rau rừng: nõi chuối rừng, bắp bi chuối rừng, bò khau, rau ngót rừng, thảo dược từ rừng: giảo cổ lam, sâm đá, sâm cau, tầm gửi và nhiều loài khác.

Như vậy, với những đặc điểm tự nhiên và những truyền thống văn hóa tốt đẹp của cộng đồng các dân tộc sống trên địa bàn, Lâm Bình có nhiều tiềm năng để phát triển du lịch. Hệ động, thực vật đa dạng, phong phú, quý hiếm, cảnh quan núi, rừng, lòng hồ hoang sơ, hùng vĩ là điều kiện quan trọng để Lâm Bình phát triển nhiều loại hình du lịch như: du lịch sinh thái, du lịch mạo hiểm, du lịch khám phá,... Cùng với bản sắc văn hóa truyền thống các dân tộc cơ bản được lưu giữ, người dân thân thiện, chân thành, giàu lòng mến khách là yếu tố quan trọng để phát triển du lịch cộng đồng, tạo những điểm nhấn, sản phẩm riêng có mà ít có địa phương nào có được.

2.2.2. Tình hình phát triển du lịch sinh thái gắn với du lịch cộng đồng

Theo thống kê của Sở Văn hóa, Thể thao \& Du lịch và Báo cáo của huyện Lâm Bình [9][11], đầu năm 2016, huyện Lâm Bình bắt đầu triển khai thực hiện thí điểm mô hình du lịch cộng đồng với điểm nhấn là các Homestay tại 04 điểm du lịch với 15 hộ tham gia mô hình tại: thôn Nà Tông, Nà Đông (xã Thượng Lâm), thôn Nà Muông (xã Khuôn Hà) và thôn Nặm Đíp (xã Lăng Can); tổ chức hội nghị chuyên đề quán triệt, triển khai và thống nhất nội dung, cách thức thực hiện các nội dung, công việc theo kế hoạch; thành lập Tổ công tác của huyện, phân công nhiệm vụ cụ thể cho từng thành viên phụ trách từng hộ, trực tiếp hướng dẫn, giúp đỡ các hộ thực hiện việc xây dựng mô hình; tổ chức cho các hộ dân thăm quan, học tập kinh nghiệm làm du lịch cộng đồng tại tỉnh Hà Giang, Hòa Bình, Thái Nguyên, đồng thời tổ chức các lớp tập huấn, hướng dẫn nghiệp vụ về du lịch cộng đồng; xây dựng phương án bảo đảm an toàn cho du khách; tuyên truyền, vận động các hộ dân gìn giữ không gian văn hóa đặc sắc của dân tộc, giữ nguyên hiện trạng, cảnh quan, kiến trúc nhà truyền thống, thực hiện chỉnh trang nhà cửa, làm nhà vệ sinh, sưu tầm các công cụ, dụng cụ sinh hoạt hàng ngày để phục vụ khách; đầu tư xây dựng cơ sở hạ tầng chung (bãi đỗ xe, đường giao thông nội bộ, bến thủy, các khu vực tổ chức các hoạt động chung,...); hạ tầng viễn thông, tài chính, ngân hàng, điện, nước sạch; thành lập 04 đội văn nghệ, tập huấn, luyện tập các tiết mục để phục vụ khách; hoàn thành xây dựng bản đồ, tuor, tuyến và nội dung thuyết minh du lịch; thành lập 03 tổ điều phối tại 03 xã để hướng dẫn, phân khách, tư vấn cho khách tham quan du lịch; xây dựng bảng giá các dịch vụ Homestay; thành lập Website Du lịch Lâm Bình, các trang Facebook và các mạng xã hội khác để tuyên truyền quảng bá du lịch. Ngày 28/6/2017, Ủy ban nhân dân tỉnh đã ban hành Quyết định số 718/QĐUBND về việc công nhận điểm du lịch địa phương tỉnh Tuyên Quang năm 2017.

Hiện tại, tại 04 điểm du lịch sinh thái cộng đồng với các nhà sàn, nhà trọ đặc trưng (Homestay) trên địa bàn có khả năng phục vụ đồng thời mỗi điểm khoảng 100 khách, với các sản phẩm chủ yếu như sau [11]:

a) Tìm hiểu văn hóa truyền thống của đồng bào dân tộc Tày, Dao, Mông, Pà Thẻn, Tộc người Thủy (cuộc sống sinh hoạt hàng ngày: bắt ốc, hái rau rừng, câu cá, bắt cua đá, chăn trâu,...); cùng thưởng thức các làn điệu dân ca, dân vũ, trò chơi dân gian truyền thống của các dân tộc (Hát quan làng, then, cọi, Páo dung, bắn nỏ, đẩy gậy, đi cà kheo, Múa khèn, đánh cù,...), nghề dệt truyền thống, nghề làm bún cổ truyền, Lễ cấp sắc của đồng bào Dao, Lễ hội Lồng Tông của đồng bào Tày, chương trình Nhảy lửa huyền bí của đồng bào Pà Thẻn,... 
b) Du khách được hòa mình vào không gian thiên nhiên tươi đẹp, núi non trùng điệp của danh thắng Thượng Lâm - 99 ngọn núi, thắng cảnh tại các xã Khuôn Hà, Lăng Can, Phúc Yên,... đi xe đạp, đi bộ tham quan bản làng văn hóa; được sống trong các ngôi nhà sàn truyền thống hàng trăm tuổi của đồng bào Tày, ngôi nhà trình tường của đồng bào Mông,... để tìm hiểu, khám phá cuộc sống sinh hoạt hàng ngày và văn hóa của nhân dân các dân tộc huyện Lâm Bình.

c) Du thuyền hoặc chèo thuyền KAYAK, đi bè mảng tham quan hồ Tuyên Quang. Tại đây quý khách sẽ có cơ hội hòa mình vào với thiên nhiên hùng vĩ, nơi được mệnh danh như "Hạ Long Cạn giữa đại ngàn"; tham quan, chụp ảnh Cọc Vài Phạ - Cọc buộc trâu trời (biểu tượng của Lâm Bình), nhà bè nuôi cá trên hồ và rất nhiều hòn đảo lớn nhỏ khác.

d) Khám phá vẻ đẹp nguyên sơ, mê hoặc của thác Khuổi Nhi, Khuổi Súng, Nặm Me, thác Hang,.... Đặc biệt du khách sẽ được hưởng dịch vụ massage miễn phí với hàng ngàn chú cá luôn sẵn sàng massage khi khách ngâm mình xuống dòng nước trong xanh, mát lạnh tại thác Khuổi Nhi. Đây là dịch vụ massage mà chỉ duy nhất nơi đây mới có.

e) Đi bộ, leo núi, ngủ lều trại, lều nương, khám phá rừng nguyên sinh, khám phá hệ thống hang động còn nguyên sơ, chưa có dấu chân con người và du khách sẽ là những người đầu tiên khám phá các hang, động: Khuổi Pín, Nặm Thuổm, Giếng Trời, Lũng Nhòi...); đi câu đêm và ngủ trên lòng hồ thủy điện Tuyên Quang.

f) Thưởng thức các món ẩm thực truyền thống, bảo đảm chất lượng và an toàn thực phẩm. Du khách có thể đặt mua các sản phẩm trên về làm quà cho gia đình, bạn bè và người thân.

g) Trên hành trình trải nghiệm, du khách có thể đến tham quan và chiêm bái nơi tâm linh - Di tích Quốc gia: chùa Phúc Lâm, đền Pú Bảo; di tích xưởng quân khí H52 của anh hùng Ngô Gia Khảm, hang Phia Vài nơi phát hiện 02 ngôi mộ táng có niên đại trên dưới 12 nghìn năm và nhiều di tích khác.

Bên cạnh những tiềm năng, thế mạnh và những việc đã làm được, phát triển du lịch sinh thái gắn với phát triển du lịch cộng đồng tại huyện Lâm Bình còn gặp phải những khó khăn, trở ngại sau: (i) Các điều kiện cơ sở vật chất phục vụ du khách của các hộ gia đình và hạ tầng du lịch chung còn thiếu, chưa đồng bộ. Kỹ năng làm du lịch của các lao động đang ở mức độ thấp, khó khăn cho việc tiếp cận, giao lưu với khách du lịch, đặc biệt là với khách du lịch nước ngoài; (ii) Hạ tầng tại các điểm danh lam thắng cảnh, di tích lịch sử, khảo cổ chưa được đầu tư xây dựng, giao thông kết nối các tuor, tuyến chưa đồng bộ, một số nét văn hóa truyền thống có nguy cơ mai một; (iii) Mặc dù đường giao thông đi lại đã được đầu tư xây dựng, bảo đảm xe ô tô đi lại thông suốt đến các khu, điểm du lịch cộng đồng. Tuy nhiên, mặt đường hẹp, xuống cấp, giao thông đi lại khó khăn, nhất là đối với các đoàn khách số lượng lớn; (iv) Chưa có nhiều sản phẩm quà lưu niệm bán cho du khách; (v) Công tác tuyên truyền, quảng bá, kết nối với các công ty, doanh nghiệp lữ hành và những người có nhu cầu đi tham quan du lịch còn hạn chế [11].

\subsubsection{Một số định hưóng về phát triển du lịch sinh} thái gắn với du lịch cộng đồng tại huyện Lâm Bình

Thứ nhất, cần tập trung xây dựng kế hoạch, phương án chi tiết, cụ thể gắn với việc thực hiện Chương trình hành động của Ban Chấp hành Đảng bộ tỉnh thực hiện Nghị quyết số $08-\mathrm{NQ} / \mathrm{TW}$ của Bộ Chính trị và Kế hoạch của UBND tỉnh triển khai thực hiện Chương trình hành động số $15-\mathrm{CTr} / \mathrm{TU}$ ngày 27/6/2017 của Ban Thường vụ Tỉnh ủy thực hiện Nghị quyết số 08-NQ/W ngày 16/01/2017 của Bộ Chính trị về phát triển du lịch trở thành ngành kinh tế mũi nhọn.

Thư hai, tiếp tục thực hiện có hiệu quả Quy hoạch tổng thể phát triển du lịch tỉnh Tuyên Quang đến năm 2020 và định hướng đến năm 2030; Kết luận số 28 KL/TU ngày 18/5/2016 của Ban Thường vụ Tỉnh ủy về nhiệm vụ, giải pháp phát triển du lịch giai đoạn 2016 2020; Kế hoạch số 51/KH-UBND ngày 23/6/2016 của Ủy ban nhân dân tỉnh Tuyên Quang và Kế hoạch số 117/KH-UBND ngày 12/10/2016 của Ủy ban nhân dân huyện Lâm Bình về phát triển du lịch giai đoạn 2016 2020.

Thứ $b a$, đẩy mạnh công tác truyền thông xúc tiến quảng bá du lịch trên website, facebook, zalo, youtube, fanpage...Thường xuyên tổ chức và tham gia các hoạt động văn hóa, du lịch để tuyên truyền, quảng bá về tiềm năng, thế mạnh du lịch của Lâm Bình. Phối hợp với các cơ quan, đơn vị, doanh nghiệp tổ chức tốt các lễ hội truyền thống tại địa phương hàng năm, góp phần bảo tồn, phát huy giá trị văn hóa truyền thống, thu hút đông đảo du khách trong và ngoài nước đến tham quan, du lịch.

Thư tux, tăng cường tổ chức các hoạt động liên kết, khảo sát, hợp tác để xây dựng các chương trình liên kết phát triển du lịch trong nước và quốc tế. Khuyến khích và tạo điều kiện cho các doanh nghiệp trong và ngoài tỉnh kinh doanh lữ hành nội địa và quốc tế tại Lâm 
Bình. Hướng dẫn, tư vấn cho các cơ sở dịch vụ du lịch nâng cấp cơ sở vật chất kỹ thuật và nâng cao chất lượng phục vụ để đón khách du lịch.

Thư năm, thường xuyên tổ chức các lớp bồi dưỡng nghiệp vụ du lịch, các cuộc thi nâng cao tay nghề du lịch, dịch vụ lữ hành, quản trị du lịch. Hỗ trợ tập huấn nâng cao nhận thức và kỹ năng phát triển du lịch sinh thái gắn với du lịch cộng đồng theo hướng bền vững cho cán bộ, học sinh, người dân trực tiếp vận hành.

Thư sáu, xây dựng sản phẩm du lịch mang tính đặc trưng riêng để thu hút khách du lịch nhằm khai thác có hiệu quả, tiềm năng, thế mạnh du lịch của huyện, của vùng du lịch. Có chính sách hỗ trợ về khôi phục, sản xuất sản phẩm du lịch, nhất là các nghề truyền thống: Dệt thổ cẩm, thủ công mỹ nghệ đặc trưng của đồng bào các dân tộc. Kêu gọi các nhà đầu tư, doanh nghiệp lập các dự án đầu tư, khai thác các khu, điểm du lịch và các loại hình du lịch huyện có tiềm năng, lợi thế; hợp tác đầu tư, chia sẻ lợi ích với các hộ dân trong quản lý, khai thác loại hình du lịch trên địa bàn.

Thư bảy, huy động và thu hút các nguồn lực đầu tư xây dựng cơ sở hạ tầng ở các khu, điểm du lịch: Điểm du lịch cộng đồng: Thôn Nà Tông, thôn Nà Đông, xã Thượng Lâm; thôn Nà Muông, xã Khuôn Hà; thôn Nặm Đíp, xã Lăng Can; thôn Thượng Minh, xã Hồng Quang; thôn Khau Cau, xã Phúc Yên và tại một số điểm danh lam, thắng cảnh khác trên địa bàn huyện. Phối hợp với các cơ quan quản lý nhà nước và các doanh nghiệp quản lý chặt chẽ tài nguyên du lịch tại các khu, điểm du lịch trên địa bàn.

Thư tám, tăng cường kiểm tra, giám sát, hướng dẫn cơ sở kinh doanh dịch vụ du lịch: Khách sạn, nhà nghỉ, nhà hàng, cơ sở mua bán các sản phẩm du lịch, phương tiện vận chuyển khách du lịch; lập kế hoạch đề nghị Sở Văn hóa, Thể thao và Du lịch làm thủ tục thẩm định, xếp hạng, cấp thẻ, cấp giấy chứng nhận hoạt động du lịch theo đúng các quy định hiện hành của Nhà nước; thẩm định thực tế, xếp hạng các cơ sở lưu trú du lịch; thẩm định hồ sơ cấp mới, đổi, cấp lại thẻ hướng dẫn viên du lịch.

\section{Kết luận}

Phát triển du lịch sinh thái ở Lâm Bình là một trong những giải pháp quan trọng nhằm khai thác tiềm năng và thế mạnh của du lịch Tuyên Quang theo Quy hoạch tổng thể phát triển du lịch tỉnh Tuyên Quang đến năm 2020, định hướng đến năm 2030 và thực hiện Nghị quyết số 08-NQ/TW ngày 16/01/2017 của Bộ Chính trị về phát triển du lịch trở thành ngành kinh tế mũi nhọn.
Để phát triển du lịch sinh thái tại huyện Lâm Bình cần đề cao quyền làm chủ, quản lý phân bổ lợi ích rộng rãi và nâng cao chất lượng cuộc sống cho đồng bào các dân tộc trên địa bàn. Đây cũng chính là ưu thế của du lịch sinh thái, du lịch cộng đồng theo hướng phát triển bền vững tại huyện Lâm Bình, góp phần phát triển du lịch sinh thái tại tỉnh Tuyên Quang và các tỉnh liên kết tuyến, vùng du lịch.

Để đảm bảo sự phát triển bền vững của du lịch sinh thái tại huyện Lâm Bình nói riêng và phát triển kinh tế xã hội của tỉnh Tuyên Quang nói chung, hoạt động du lịch sinh thái cần được đẩy mạnh trên cơ sở khai thác hợp lý thế mạnh, tiềm năng của tài nguyên du lịch sinh thái tại Lâm Bình và kết nối với các tuyến, các vùng du lịch khác trong và ngoài tỉnh. Muốn vậy, cần phải có sự kết hợp đồng bộ giữa chủ trương đường lối chính sách của Đảng và nhà nước, quản lý điều hành của chính quyền địa phương và sự tham gia của cộng đồng dân cư trên địa bàn.

\section{TÀI LIÊU THAM KHẢO}

[1] Chính Phủ (2011), Chiến lược phát triển du lịch Việt nam đến năm 2020, tầm nhìn 2030, ban hành theo Quyết định số 2473/QĐ-TTg ngày 30/12/2011 của Thủ tướng Chính phủ.

[2] Chính Phủ (2013), Quy hoạch tổng thể phát triển du lịch Việt Nam đến 2020, tầm nhìn 2030, ban hành theo Quyết định số 201/QĐ-TTg ngày 22/01/2013 của Thủ tướng Chính phủ.

[3] Chính phủ (2014), Quy hoạch tổng thể phát triển kinh tế-xã hội vùng trung du miền núi phía Bắc đến 2020, ban hành kèm theo Quyết định số 1064/QĐ-TTg ngày 08/7/2014 của Thủ tướng Chính phủ.

[4] Lê Huy Bá (2009), Du lịch sinh thái, Nxb Khoa học kỹ thuật, Hà Nội.

[5] Cổng thông tin điện tử tỉnh Tuyên Quang, Kế hoạch số 51/KH-UBND ngày 23/6/2016 của Ủy ban nhân dân tỉnh Tuyên Quang về phát triển du lịch tỉnh Tuyên Quang giai đoạn 2016 - 2020.

[6] Đỗ Trọng Dũng (2009), "Đánh giá điều kiện tự nhiên để phát triển du lịch sinh thái ở tiểu vùng du lịch miền núi Tây Bắc Việt Nam”, Luận án Tiến sĩ, Trường Đại học Sư phạm Hà Nội.

[7] Thế Đạt (2003), Du lịch và du lịch sinh thái, Nxb Lao động, Hà Nội.

[8] Luật Du lịch (2017), Nxb Chính trị Quốc gia Sự thật, Hà Nội. 
[9] Sở Văn hóa, Thể thao và Du lịch Tuyên Quang (2017), Báo cáo kết quả thực hiện nhiệm vụ phát triển du lịch theo Nghị quyết Đại hội Đảng bộ tỉnh Tuyên Quang lần thứ XVI (khóa 2016-2020).

[10] Ủy ban nhân dân huyện Lâm Bình (2016), Kế hoạch phát triển du lịch Lâm Bình giai đoạn 2016-2020.
[11] Ủy ban nhân dân huyện Lâm Bình (2017), Báo cáo tiềm năng và tình hình phát triển du lịch cộng đồng huyện Lâm Bình.

\section{Ecotourism development in Tuyen Quang: case study of Lam Binh District}

Nguyen Khai Hoan, Nguyen Phuong Thao, Nguyen Van Hien

\section{Article info}

Recieved:

15/11/2018

Accepted:

10/12/2018

Keywords:

Tourism development, ecotourism; Lam Binh ecotourism, Tuyen Quang ecotourism

\begin{abstract}
Eco-tourism is one of the strongly growing types of tourism that attracts both domestic and international tourists. Ecotourism is seen as an effective solution to protect the ecological environment towards sustainable development by reducing the pressure of exploiting natural resources, serving the needs of visitors and local residents when participating in ecotourism activities associated with the community. This article analyzes and clarifies some issues on the potentials, strengths and solutions for ecotourism development in Tuyen Quang through case studies of Lam Binh District.
\end{abstract}

